\title{
Tolerance of Plants in Response to Abiotic Stress Factors
}

\author{
Rupnarayan Sett* \\ Department of Genetics and Plant Propagation, Tropical Forest Research Institute, India
}

Submission: May 30, 2017 , Published: June 13, 2017

*Corresponding author: Rupnarayan Sett, Department of Genetics and Plant Propagation, Tropical Forest Research Institute (ICFRE; MoEFCC), Mandla Road, PO RFRC, Jabalpur 482021, Madhya Pradesh, India, Email: ruppuran2001@yahoo.co.in/settrn@icfre.org

\section{Introduction}

Immobile plants can't evade abiotic stress factor, this feature enables them to develop distinctive molecular mechanisms to deal with different pressure aspects; though, variations do exist in tolerance mechanisms. In some plants, morphological modifications have made them able to avoid stress factors. The best option lies for them is to change their biochemical and physiological activities to combat the stress.

Abiotic stresses are caused by water scarcity or drought, excess of salts or over-salinity, beyond-tolerance temperatures, intensity and photoperiodicity of light, nutrient-deficiency or excessiveness, prevalence of heavy-metal elements, air- or water- pollution, etc. These factors may affect the plants as individual factor or in combinations, which may change the metabolic processes affecting to less growth, development and productivity (Figure 1). In case of extreme stress, it will cause unbearable metabolic load on the cells leading to death of the plant. The plants are not totally free from stress in nature. To fight these stresses, plants develop several procedures to combat that with the generation of unique molecules and metabolic pathways for stress acceptance.

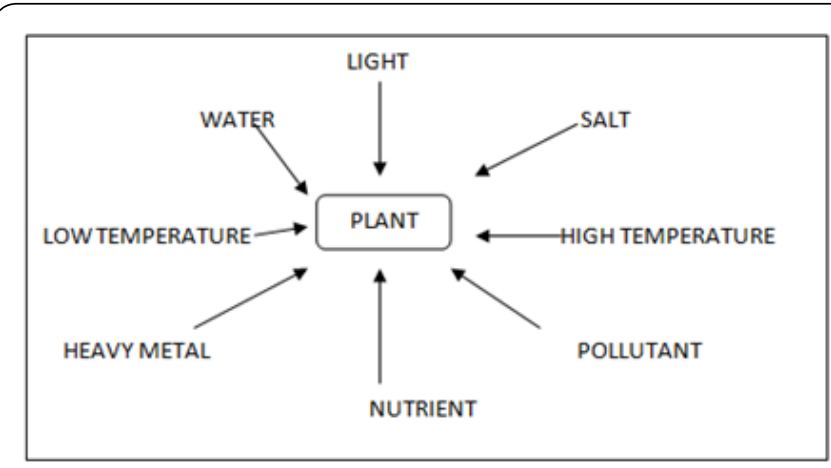

Figure 1: Some common abiotic stress factors that affect plants.
The methods to evade the stresses are sometimes the alterations in morphology and anatomy, which prevent plants from different stress issues; these changes are very important in generating stress-tolerance in plants. Most of the stress factors produce certain common effects on plants; one of those is the membrane systems which carry out several lives sustenance activities. Each of the membrane-related actions gets influenced by the abiotic stresses.

The molecules found always associated with aerobic life are the Active Oxygen Species or AOS [1]. All abiotic stresses viz. water-stress, salt-stress, temperature-stress, light-stress, nutrient-stress, heavy metal-stress and pollution-stress accelerate the creation of AOS in plants that injure to membrane systems and other cellular processes [2-4]. Both enzymatic and non-enzymatic anti-oxidative systems impose significant roles in stabilizing and avoiding oxidative damage $[5,6]$. Depending on the type of plant and genetic structure of the plant. In spite of the close relationship of active oxygen species with aerobic life, their production, role, stress-connection, importance in signaling phenomena and their scavenging are not clearly revealed. Abiotic stresses influence carbon-assimilation, respiration, transpiration, growth, nitrogen assimilation, protein synthesis and gene expression (Figure 2). To cope up the consequences, plants grow specific tolerance mechanisms like modified gene expression, accumulation of attuned solutes, increase of polyamines, generation of ATP molecules, commencement of signaling factors, increased anti-oxidative metabolism, ion-homeostasis, regulation of hormonal equilibrium, intracellular partitioning of cellular substances and metabolic activities by membranes, assisted membrane transport and production of stress-proteins, though, the level of tolerance differs low to high from plant to plant. 


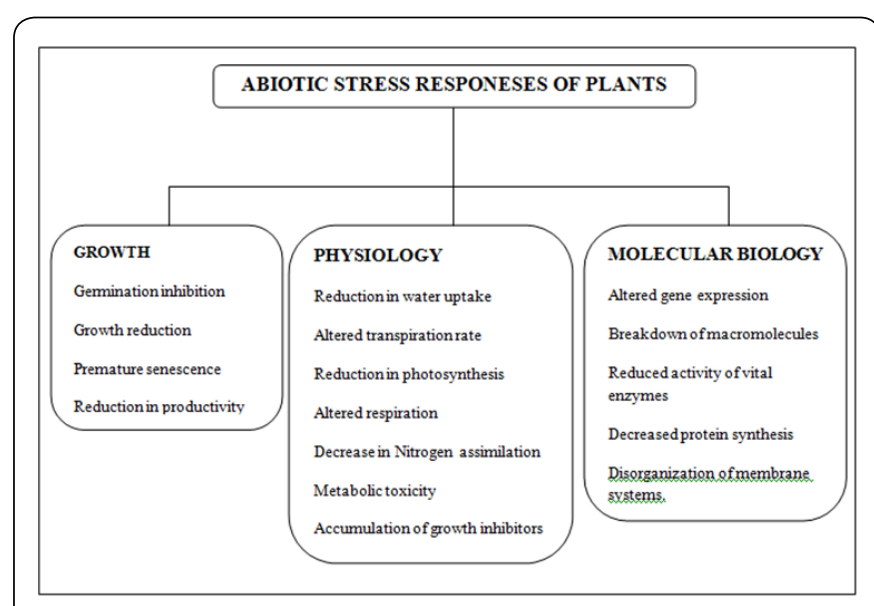

Figure 2: Some of the common plant responses to abiotic stresses.

Unique molecules and their new functions, innovative concepts and novel molecular mechanisms, explorations of products from stress-inducible-genes, significance of signaltransduction pathways and functional genomics enrich the research area of abiotic stress tolerance (Figure 3). Acceptance of methods to cope-up stressful situations starts with stress perception inducing creation of gene products that are engaged in cellular-defense and repair mechanisms. The signal transduction pathways that sense stresses, participate in an essential function in the initiation of tolerance in plants, one of which is by gene transfer [7]. Diverse physiological and molecular methods in connection with the uses of plant breeding and genetic engineering can advance the possibility for stress tolerance in plants.

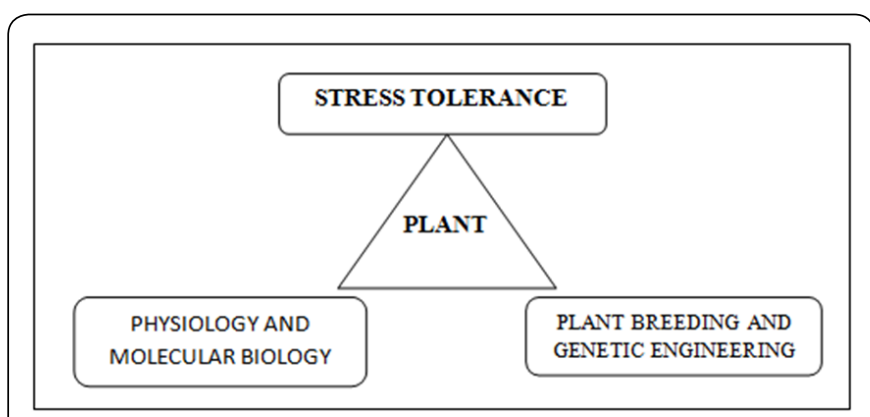

Figure 3: Knowledge of physiology and molecular biology combined with plant breeding and Genetic engineering techniques are expected to enhance stress tolerance in plants.

\section{References}

1. Vranova E, Inze D, Van Breusegem F (2002) Signal transduction during oxidative stress. J Exp Bot 53(372): 1227-1236.

2. Dat J, Van Denabeele S, Varanova E, Van Montagou M, Inze D, et al. (2000) Dual action of the active oxygen species during plant stress response. Cell Mol Life Sci 57(5): 779-795.

3. Mittler R (2002) Oxidative stress, antioxidant and stress tolerance. Trends Plant Sci 7(9): 405-410.

4. Mittler R, Vanderauwera S, Gollery M, Van Breusegem F (2004) Reactive oxygen gene network of plants. Trends in Plant Sciences 9(10): 490-498.

5. Bowler C, Van Camp W, Van Montagu M, Inze D (1994) Superoxide dismutase in plants. Critical Reviews in Plant Sciences 13(3): 199-218.

6. Foyer CH, Descourvieres P, Kunert KJ (1994) Protection against oxygen radicals: an important defense mechanism studied in transgenic plants. Plant, Cell and Environment 17(5): 507-523.

7. Smalle J, Vierstra (2004) the ubiquitin $26 \mathrm{~S}$ proteo some proteo lytic pathways. Annu Rev Plant Biol 55: 555-590.

Your next submission with Juniper Publishers
will reach you the below assets
- Quality Editorial service
- Swift Peer Review
- Reprints availability
- E-prints Service
- Manuscript Podcast for convenient understanding
- Global attainment for your research
- Manuscript accessibility in different formats
( Pdf, E-pub, Full Text, Audio)
- Unceasing customer service
Track the below URL for one-step submission
https://juniperpublishers.com/online-submission.php

